\title{
Between Hermeneutics and Aesthetics: Reconsidering Truth and Method as an "Aesthetics of Truth"
}

\author{
Patrick Martin \\ Faculty of Arts \\ University of Helsinki \\ patrick.martin@helsinki.fi
}

Received 31 January 2018; accepted 29 April 2018; published 30 September 2018.

\begin{abstract}
The focus of the paper is on Gadamer's claim that "Aesthetics has to be absorbed into hermeneutics." Our initial aim is to contextualize the statement, emphasizing its controversial nature, given that the context specific meaning of the claim can seem commonsensical. Accordingly, the first part of the paper is devoted to developing the historical tension between philosophy and art. Towards the latter half of the paper, the task is to examine Gadamer's thesis in light of this history. Evaluating Gadamer's position within the philosophical tradition, we will take recourse to Bubner's critique of an "aesthetics of truth." While judging Bubner's critique to be accurate, we will also stress certain peculiarities that potentially undermine his critique - especially as it concerns Gadamer. Here, the most critical aspect has to do with his critique of the notion of "the work," which figures as the cornerstone of his critique of modern-day aesthetic theory. We will show that insofar as Bubner argues from a critique of the work anchored in modern art, then, as far as Gadamer is concerned, he is arguing from a notion of the work that was never theoretically espoused to begin with. We will conclude with an argument for the claim that the artwork on Gadamer's account is hermeneutically structured. For only on such a conception, we argue, can he be taken as living up to his promise of doing justice to the experience of art.
\end{abstract}

Keywords: aesthetic non-differentiation; aesthetics; art; Bubner; experience; Gadamer; hermeneutics. 


\section{Introduction}

The focus of this paper ${ }^{1}$ will be on Gadamer's claim that "Aesthetics has to be absorbed into hermeneutics" (1960/1989, p. 164). Our initial aim will be to contextualize the statement, emphasizing its controversial nature, in that the context specific meaning of the claim can seem commonsensical. We will therefore begin by projecting the thesis onto the historical tension between philosophy and art. Towards the latter half of the paper, our task will be to examine Gadamer's thesis within the context of what it means to understand art. Linking the claim above to developments within the philosophical tradition, we will take recourse to Bubner's critique of an "aesthetics of truth." While judging Bubner's critique to be accurate, we will also stress certain peculiarities that potentially undermine his critique of Gadamer. Here, the most critical aspect has to do with his critique of the notion of "the work," which figures as the cornerstone of his critique of modern-day aesthetic theory. We will show that insofar as Bubner argues from a critique of the work anchored in modern art, then, as far as Gadamer is concerned, he is arguing from a notion of the work that was never theoretically espoused to begin with. We will conclude with an argument for the claim that artwork is hermeneutically structured. For only on such a conception, we argue, can Gadamer be taken as living up to his promise of doing justice to the experience of art.

\section{Art for Philosophy}

To begin with, let us briefly consider the relationship between philosophy and art in the philosophical tradition. The purpose of the following historical overview is to get a sense of the possible implications entailed by Gadamer's claim for the priority of the hermeneutic perspective. We shall here limit ourselves to only pointing out certain general tendencies, focusing specifically on how philosophy has approached art. Later, when turning to Bubner's critique, we will see that these tendencies are still present in Truth and Method (Gadamer, 1960/1989).

Philosophy has been portrayed as entering the scene in competition with art. In the Republic, even Socrates refers to "a long-standing dispute between philosophy and poetry" (607b). Plato's critique of poetry does not, however, seem to be primarily an aesthetic one, but rather of epistemic nature. What is the significance of philosophy placing itself in opposition to art? Why would philosophy single out art, viewing it as its closest "rival"? A description of this quarrel that clearly brings out the complex nature of this historical fact has been succinctly offered to us by Figal. He writes as follows:

philosophy has viewed art, more specifically poetry, under the guise of insight. Philosophy's claim to knowledge was formulated in competition with poetry, and that only makes sense if poetry is either knowledge or at least counts as knowledge. Only then can poetry be shown to be insufficient in comparison to philosophy; only then can one argue whether poetry is truly knowledge, such that philosophy gains in profile through comparison with it. (2010/2015, p. 10; emphasis added)

\footnotetext{
${ }^{1}$ Acknowledgements: the paper was written with financial support from Nylands Nation.
} 
Today, Figal adds, this "competitively construed comparison between the artist and the philosopher yields so little" partly because philosophy is well established and does not need to be "distinguished from other forms of world-disclosure in order to show its peculiar profile" (2010/2015, p. 14). However, as we shall see philosophy is still very much attached to art.

\section{In Competition or in Cooperation?}

Welsch proposes that we can crudely describe the historical development of this relationship as dominated either by competition (incommensurability) or cooperation (commensurability). He (1996, pp. 212-213) suggests that even though the conflict between art and philosophy has taken different forms throughout history, there is a clear demarcation with the advent of traditional aesthetics. Around 1800 there was a clear change in the relationship. Whereas earlier the relationship between philosophy and art was mostly one of competition, the rise of traditional aesthetics reoriented the relationship to one of cooperation. The change takes place when art becomes the object of interpretation. As an object of interpretation, art needs to be commensurable with philosophy on some level-otherwise there can be no question of a task of interpretation. This does not rule out the possibility that on a secondary level there might still remain an essential difference between the two. However, as Figal's description above showed us, such a neat distinction between competition and cooperation is in a sense already compromised by the initial set-up: the competition already bears the seeds to the subsequent cooperation.

However, even though the relationship between philosophy and art can be described as turning from competition to cooperation, this does not imply that art in the eyes of philosophy would have gained an equal footing. For Welsch the commensurability thesis of traditional aesthetics is best exemplified by Hegel, which rests on two principal premises: first, that the truth of art is similar (gleichartig) or commensurable with the truth of philosophy; and secondly, that the truth of art is only sensuously confined, ${ }^{2}$ needing philosophy to be freed and translated into concepts (1996, p. 218).

Traditional aesthetics, Welsch argues, is still unsuitable for a hermeneutics of art: in that for traditional aesthetics the question is still about philosophy rather than about understanding art. Traditional aesthetics, he maintains, does not want to comprehend art but rather to appropriate it for philosophy; in short, art is seen as merely awaiting its substitution by philosophy.

Historically, the position of commensurability leads to the antithetical position of arguing for the incommensurability between art and philosophy. In Aesthetic Theory (1970/1986), for example, Adorno expresses the sentiment concisely in the following: "Aesthetics cannot hope to grasp works of art if it treats them as hermeneutical objects. What at present

\footnotetext{
2 "nur in sinnlich eingeschränkter Form vorliege” (Welsch, 1996, p. 218).
} 
needs to be grasped is their unintelligibility" (p. 173). However, as we shall later see, even critical theory is no different from $20^{\text {th }}$ century hermeneutics, according to Bubner: they are both captured arguing from a standpoint of truth.

\section{The Modern and the Postmodern}

Glancing quickly at the recent history of art, there is with postmodernism, on Danto's (2014) account, a turn towards philosophy on the part of art. He characterizes modern art as representing a materialist aesthetics and postmodern art as an aesthetics of meaning. The shift towards what Welsch calls a position of incommensurability can be described as how modern art understands itself: becoming focused on materiality, modern art asks how its medium makes it different. Thus, in modern art the focus is on the conditions of representation: in other words, the medium becomes the subject matter of art (Danto, 2014, pp. 7, 67).

What then happens with the advent of the ready-mades - which for Danto is epitomized by Warhol's Brillo Box - is that art becomes philosophical, confronting the viewer with the question "why am I art?" Danto writes,

It meant that as far as appearances were concerned, anything could be a work of art, and it meant that if you were going to find out what art was, you had to turn from sense experience to thought. You had, in brief, to turn to philosophy. (2014, p. 13)

In other words, we can say that when art questioned the supposedly evident distinction between art and things useful, the viewer felt compelled to reach for "philosophy"3_for some sort of conceptual grounding.

Modernism came to an end when [...] works of art and mere real objects could no longer be articulated in visual terms, and it became imperative to quit a materialist aesthetics in favor of an aesthetics of meaning. This, again in my view, came with the advent of pop. (Danto, 2014, p. 77)

Danto, alternatively, describes postmodern art as post-historical. This label comes from the fact that after the "Age of Manifestos," there is according to him no longer any stylistic unity to art: that is, once the difference between artworks and real things is questionedas exemplified by Duchamp - anything can become a work of art and the historical development of art is done away with (2014, p. 113). Of course, if postmodern art is truly posthistorical, then this master narrative that Danto serves us must also be considered limited or one-sided (Rebentisch, 2015, p. 130).

\section{5. "Aesthetics has to be absorbed into hermeneutics"}

So far, we have looked at the historical tensions between philosophy and art. Let us now turn to Gadamer's claim - “Aesthetics has to be absorbed into hermeneutics"- that has occasioned this historical excursion. In what follows, we will be considering this thesis in

\footnotetext{
${ }^{3}$ Danto's hasty equation of "thought" with "philosophy," should be taken with some reserve, lest it lead us astray.
} 
two ways: first, as a more modest claim about perception, and secondly, as a thesis about Gadamer's general approach to art.

As concerns the first point, we could take "aesthetics" as simply indicating "aesthetic consciousness" - one of Gadamer's primary points of critique in Truth and Method. This reading is supported by the context, in that Gadamer frames his thesis as follows: "hermeneutical consciousness [has] a comprehensiveness that surpasses even that of aesthetic consciousness. Aesthetics has to be absorbed into hermeneutics" (1960/1989, p. 164). ${ }^{4}$ Gadamer argues a great deal for the priority of the hermeneutic perspective. However, when it comes to the aesthetic, it is primarily engaged with through a critique: that is, a critique of "aesthetic consciousness" and its mode of judgement based on "aesthetic differentiation."5 There is, therefore, a challenge in saying anything more substantial about how the aesthetic figures within the hermeneutic phenomenon.

Gadamer's argument for the priority of hermeneutic consciousness boils down to the claim that aesthesis, the sensuous, does not account for how we see things (1960/1989, pp. 8990; 1960/1990, pp. 95-96). In "The relevance of the beautiful” (1974/1986), for example, Gadamer briefly claims that "it is a secondary procedure if we abstract from whatever meaningfully addresses us in the work of art and wholly restrict ourselves to a 'purely aesthetic' evaluation" (p. 29). ${ }^{6}$ Elsewhere, Gadamer maintains that

We are always hearing - listening to something and extracting from other things. We are interpreting in seeing, hearing, receiving. In seeing, we are looking for something; we are just not like photographs that reflect everything visible [...] So it is obvious that there is a real primacy of interpretation. (1984, pp. 59-60)

Of course, this way of reading Gadamer's thesis, that is, reducing it to the modest claim that aesthetic consciousness (considered as a derivative mode of consciousness) has to be absorbed into hermeneutic consciousness, does not quite account for all of the implications present. "Aesthetics" does not only signify the sensuous, and "hermeneutics" is not simply reducible to wahr-nehmen - taking something as something, as something true. In other words, even though the "aesthetic" can generally be taken as designating that which pertains to the sensuous, "aesthetics" usually refers to art. Welsch $(1996$, p. 22) points out that "aesthetics" is a particularly polyvalent word: it has variously been used to refer to the sensuous, the beautiful, nature, art, perception, judgement, and knowledge. Therefore, we cannot read Gadamer's claim above as only being a thesis about perception.

\footnotetext{
${ }^{4}$ For the German original see Gadamer (1960/1990, p. 170).

${ }^{5}$ See Gadamer (1960/1989, pp. 86-87, 117; 1960/1990, pp. 92-93, 122).

${ }^{6}$ See Gadamer (1974/1993d, p. 120).
} 
Also, simply taking Gadamer's thesis as saying that art is not reducible to "aesthetic perception" would be unremarkable. ${ }^{7}$ It would be unremarkable, first of all, in that Gadamer's primary concern is not perception. In addition, considering Welsch's terminological comment above, taking "aesthetics" narrowly as only a question of aisthesis - although etymologically correct — seems like a reduction of the term. In other words, claiming that aesthetic perception is equal to the aesthetic experience could be said to make for a poor notion of the experience of art. This is not to say that the experience of art does not include aesthetic perception.

However, secondly and more importantly, what Gadamer needs to account for in defense of his thesis is how his account of the experience of art remains valid for understanding texts in general: which is to say, he has to provide a link between aesthetics and hermeneutics. It is perhaps no coincidence that this claim - that here holds our attention - is situated in the last subchapter of part one of Truth and Method. There, before introducing his thesis, Gadamer attests to the problem just mentioned. He recapitulates the key arguments he has made so far - that the artwork becomes actualized in presentation much like the literary work is actualized when read-and then formulates his principal concern as follows:

We must ask whether what we found to be true of the experience of art is also true of texts as a whole, including those that are not works of art [...] Is the meaning of all texts actualized only when they are understood? In other words, does being understood belong [gehört] to the meaning of a text just as being heard [Zu-Gehör-Bringen] belongs to the meaning of music? Can we still talk of understanding if we are as free with the meaning of the text as the performing artist with his score? $(1960 / 1989, \text { p. } 164)^{8}$

\section{Bubner's Critique}

Bubner's critique reminds us that the overriding argument of Truth and Method echoes the "dispute" between philosophy and art. Also in light of this fact, it would be misleading to consider Gadamer's thesis only in the narrow sense as an argument about perception. Bubner criticizes $20^{\text {th }}$ century aesthetics in general as what can be termed an "aesthetics of truth" - targeting hermeneutics and critical theory alike. According to him, the gesture pointed out in the beginning of the paper, philosophy seeking its self-understanding through art, is still prevalent today. Even though Figal notes that this "rivalry" nowadays should yield little - in that philosophy has established itself - according to Bubner, philosophy is still very much dependent upon art. In addition, philosophy's approach to art continues to be determined by its own concerns: art is still judged from the point of view

\footnotetext{
${ }^{7}$ However, let us note that within the phenomenological tradition, Gadamer's thesis as elucidated thus far is not uncontroversial: Dufrenne (1953/1973), for example, maintains that aesthetic perception is precisely "the only kind of perception which does it [the work of art] justice" (p. lxv). In addition, for him perceiving the artwork as a work of art, means exactly perceiving it aesthetically.

${ }^{8}$ See Gadamer (1960/1990, p. 169).

${ }^{9}$ The shorthand "Wahrheitsästhetik” was coined by Rebentisch (2015, p. 42).
} 
of truth. In this sense, Bubner (1973, p. 40) argues that Adorno and Benjamin converge towards Heidegger and Gadamer: they are all focusing on art as a place of truth. In other words, according to Bubner (1973, p. 42), so long as art is essentially tied to a notion of truth, philosophical hermeneutics and critical theory argue in the same direction despite reaching opposite conclusions.

Bubner's critique of modern-day aesthetics as aimed at Gadamer is both accurate and peculiar. As we shall see, Bubner's depiction of an "aesthetics of truth" captures features exceedingly present in Truth and Method. However, his critique is also peculiar in two prevalent ways: first, in that it is based on a critique of a notion of the work (of art) that we have difficulty finding in Gadamer's hermeneutics. Second, in that when Bubner formulates his own positive account of the aesthetic experience (Erfahrung), pointing to Kant's Kritik der Urteilskraft as the only methodological way out, he, in a sense, positions himself quite close to Gadamer. This second peculiarity arises from reflective judgement being selected as the model for a notion of aesthetic experience $(1973$, p. 65$) .{ }^{10}$

We shall, however, only apply ourselves to the first peculiar element, in that it is the more crucial element when considering the potency of Bubner's critique. Let us start by considering how Bubner characterizes Gadamer's approach to art by describing the dominant tendencies of modern-day aesthetic theory. Bubner points out a peculiar tension that characterizes philosophy's relation to art during the $20^{\text {th }}$ century. On the one hand, philosophy approaches art projecting its own concerns and problems upon it - mainly the question of truth. In Bubner's words, philosophy interprets art in the light of its own problems and tasks art with finding a solution (1973, p. 41). ${ }^{11}$ In short, art, which according to its definition as fine art is supposed to stand against the useful tool, has been put to work for philosophy. Provokingly, we could say that art has been instrumentalized by philosophy. Gadamer himself often points out that artworks are not there for use (1972/1993c, p. 82). ${ }^{12}$ Of course, this is not to say that art and the aesthetic experience cannot incite reflection or that the practice of art could not be instructive for philosophy. In defense of Gadamer, we could argue that art not being a tool only pertains to how art appears to us - to the "there" $(d a)$ of its being.

Nevertheless, on the other hand, according to Bubner, philosophy places art as a model or mirror for itself. In his words, philosophy does not tell us what art is, rather it is art that should show us what philosophy is $\left(1973\right.$, p. 40). ${ }^{13}$ Even Figal utters this hope by wishing

\footnotetext{
${ }^{10}$ Gadamer (1974/1986, p. 29; 1974/1993d, p. 120) takes his notion of aesthetic non-differentiation (which we shall conclude with) to be essentially an elucidation on Kant's reflective judgement.

11 "Die Philosophie deutet Kunst von vornherein im Lichte ihrer eignen Problematik und stellt sie entschlossen in den Dienst [emphasis added] an deren Lösung” (Bubner, 1973, p. 41).

12 “zum Gebrauch [nicht] da ist” (Gadamer, 1972/1993c, p. 82).

13 "Die Philosophie sagt nicht, was die Kunst ist, eher soll die Kunst zeigen, was die Philosophie ist" (Bubner, 1973, p. 40).
} 
philosophy to gain a renewed sense of self-understanding as observational through art. ${ }^{14}$ The tension characterizing philosophy's relation to art can thus be summarized under the heading of an "aesthetics of truth," which emphasizes that philosophy approaches art with a primary concern for truth, while at the same time, placing art as the model for philosophy.

\section{7. "Aesthetics of Truth" in Truth and Method}

\subsection{First Aspect}

Let us then consider Truth and Method and see how these two elements of the aesthetics of truth figure there. Looking at the introduction to Truth and Method, we find the question of truth taking center stage. The truth in question is, of course, not that of scientific truth. The experience of truth corresponding to the hermeneutic phenomenon "transcends the domain of scientific method" (Gadamer, 1960/1989, p. xxii). ${ }^{15}$ Nevertheless, the phenomenon Gadamer's hermeneutics is looking for is still "concerned with knowledge and with truth." $\mathrm{He}$ explicitly notes that the "philosophic importance of art" lies in the "fact that through a work of art a truth is experienced" (1960/1989, pp. xxii-xxiii). ${ }^{16}$ He goes on to specify that in order to defend such an experience of truth, we need to do away with aesthetic consciousness. In Grondin's (1999/2003) rendition there is, consequently, "something like an 'antiaesthetic' in Gadamer's philosophy" (p. 22), which manifests itself in the argumentative move that in order to get to the truth of art we must destroy aesthetic consciousness.

If, siding with Bubner, we were to consider an aesthetics of truth incapable of appreciating art as art, we could very well ask if Gadamer's approach is a viable one? The general worry can be expressed thus: can we approach art with a concern for truth, if this is a concern that art does not share with us? Gadamer's retort would be that aesthetic theorylike the human sciences in general - has been affected by a scientific conception of truth that is too narrow. However, the worry expressed in this question gains in force when we read, in the afterword to Truth and Method, that "aesthetic non-differentiation"-which Gadamer proposes in place of the aesthetic differentiation performed by aesthetic consciousness - “does not experience art as art" yet, for him, constitutes "the real experience of art" $(1960 / 1989$, p. 573$) .{ }^{17}$ What can it then mean to view art as art? ${ }^{18}$

\footnotetext{
14 "Thus, through art, philosophy gains independence from all that has befallen the concept of theory in modernity and modernism. Instead of relinquishing its theoretical character to art, philosophy can discover it anew" (Figal, 2010/2015, p. 14).

${ }^{15}$ See Gadamer (1960/1990, p. 2).

${ }^{16}$ See Gadamer (1960/1990, p. 2).

${ }^{17}$ See Gadamer (1972/1993a, p. 472).

${ }^{18}$ A crucial point Gadamer makes by introducing his notion of aesthetic non-differentiation is maintaining that art cannot be experienced only as art.
} 
The notion that the experience of art should not be reduced to the aesthetic is mirrored in Gadamer's larger aim of developing a notion of the hermeneutic experience based on the "experience of truth that comes to us through the work of art" (1960/1989, p. xxiii). ${ }^{19}$ This view implies that the experience of art is not considered special or wholly distinct from understanding in general. According to Gadamer, "the experience of the work of art includes understanding, and thus itself represents a hermeneutical phenomenon" (Gadamer, 1960/1989, p. 100). ${ }^{20}$

However, in what sense do we need to conceive of the aesthetic experience as part of the hermeneutic experience? Is there a sense in which the experience of art must be conceived of as having phases - aesthetic perception constituting only part of the experience? Even though art in general can be said to require interpretation, Figal (2016, p. 224) argues against Gadamer, maintaining that we need to conceptually differentiate between a hermeneutic experience of meaning and an aesthetic experience, which is experienced sensibly (2010/2015, p. 27).

The principal problem Figal sees in Gadamer's considerations of art, is that, for him, Gadamer cannot avoid presupposing the differentiation characteristic of aesthetic consciousness - "otherwise, he could not speak of 'artworks' at all” (2016, p. 224). Figal aims his critique at Gadamer's notion of aesthetic non-differentiation as the guiding concept describing the experience of art, and concludes the following:

Hermeneutical experience of artworks cannot be led by an 'aesthetic non-differentiation' [...] Rather, it must also be aesthetic, and thus it cannot be reduced to the hermeneutical experience of meaning. Accordingly, aesthetics, understood as the philosophical inquiry of art, cannot be included in hermeneutics. (2016, p. 224; emphasis added)

For Figal, the experience of art, when reducing it to its bare essential elements, must be considered aesthetic. Whereas Gadamer maintains that the experience of art is "a hermeneutical phenomenon." The crucial question here seems to be how we are to take this aesthetic element as given. Figal's objection leads us to wonder why Gadamer chose to coin his term aesthetic non-differentiation, instead of, for instance, speaking of a hermeneutic non-differentiation.

\subsection{Second Aspect}

As we arrive at the second element of an aesthetics of truth in Truth and Method - art functioning as the model for philosophy — we can at length cite the section where the thesis under inspection occurs. Gadamer writes as follows,

hermeneutical consciousness [has] a comprehensiveness that surpasses even that of aesthetic consciousness. Aesthetics has to be absorbed into hermeneutics. This statement not only reveals

\footnotetext{
${ }^{19}$ See Gadamer (1960/1990, p. 3).

${ }^{20}$ See Gadamer (1960/1990, p. 106).
} 
the breadth of the problem but is substantially accurate. Conversely, hermeneutics must be so determined as a whole that it does justice to the experience of art. $(1960 / 1989, \text { p. } 164)^{21}$

As concerns the second element, the last sentence quoted expresses this sentiment precisely: hermeneutics for Gadamer "must be so determined" or so defined that it in incordance with the experience of art. This seems to presuppose an adequate grasp of the experience of art-for how else could art function as a model for hermeneutics? Yet, let us pause and ask, how can we take the experience of art as a model? For Figal, the question of art functioning as a model seems rather self-evident: "aesthetics essentially is phenomenology" (2010/2015, p. 3). However, what if our point of departure is not the aesthetic? Should we then heed Vattimo's advice? For him, "Hermeneutics is itself 'only interpretation.' Its own claims to validity are not founded on a presumption of access to the things themselves" (1992/1997, p. 108). This then, for Vattimo, means that the hermeneutics of Truth and Method cannot "put forward an explicit 'foundation' of hermeneutics to which one can appeal as proof of, or at least as a persuasive argument for, its general validity" $(1992 / 1997$, p. 103). If such a foundation were to be offered, it would, for him, be a contradiction in terms.

\section{Critique of the Concept of the Work}

The tendencies of the "aesthetics of truth" that Bubner points out aptly identify the thrust of Gadamer's Truth and Method. However, when Bubner argues that every such aesthetics necessarily relies upon a notion of the work as the bearer of truth, ${ }^{22}$ his critique as targeting Gadamer becomes increasingly problematic. Let us consider the matter in more detail. His critique of an "aesthetics of truth" boils down to an elaboration on the crisis of the notion of the "work" that is initiated by modern art. Bubner calls the crisis of the concept of the work an essential sign of the modern epoch $\left(1973\right.$, p. 62). ${ }^{23}$

For him any aesthetics that argues that art is a source of truth necessarily relies upon a category of the work. ${ }^{24} \mathrm{He}$ defines the concept of the work that modernism does away with in the following fashion: the work is that wherein objective givenness and a non-empirical content of meaning is thought of as identical — in the work, truth realizes itself as sensuous

\footnotetext{
21 "Damit erhält das hermeneutische Bewußtsein eine umfassende Weite, die diejenige des ästhetischen Bewußtseins noch übertrifft. Die Ästhetik muß in der Hermeneutik aufgehen. Das ist nicht nur eine Aussage, die den Umfang des Problems betrifft, sondern sie gilt erst recht inhaltlich. Die Hermeneutik muß nämlich umgekehrt im ganzen so bestimmt werden, daß sie der Erfahrung der Kunst gerecht wird" (Gadamer, 1960/1990, p. 170).

22 “als Träger anschaulicher Wahrheit” (Bubner, 1973, p. 61).

23 “die Krise des Werkbegriffs ein wesentliches Signum der modernen Epoche” (Bubner, 1973, p. 62).

24 “Je nachdrücklicher Kunst auf das Präsentmachen von Wahrheit verpflichtet wird, desto unerläßlicher ist die Werkkategorie etabliert” (Bubner, 1973, p. 49).
} 
intuition (1973, p. 49) ${ }^{25}$ One of the problems of Bubner's definition of the work is that it remains quite general, so that it remains difficult to pinpoint what exactly is reproachable. To claim that all objective givenness leads us astray, into a frowned upon aesthetics of truth, seems like an exaggeration. Rebentisch (2015, pp. 140-141) shows us a case in point with conceptual art and how it runs into difficulties when arguing for the secondary nature of the materially present work of art. Yet Bubner (1973, p. 63) applauds Kant for abstaining from making any further assumptions about what stands against us, maintaining that we should keep our focus strictly on the experience and its effects. ${ }^{26}$ Of course, if Bubner is merely acknowledging the fact that picking out essential characteristics necessarily present in all artworks is highly difficult, then his reticence is founded.

Consequently, we shall take our cue from the critique of the category of the work of art initiated by modern art, to which Bubner repeatedly refers. Now, it is true that Gadamer maintains that the artwork has a recognizable identity. However, this identity does not strictly correspond to the traditional idea of the closed work that modernism challenges. For Gadamer the artwork is both closed and open, ergon and energeia-it has the structure of a game, but one that must be played. In other words, the artwork is not just Werk, but Gebilde (1960/1989, p. 110; 1960/1990, p. 116). Thus, we can say that for Gadamer the work of art should be understood "as both noun and verb" (Arthos, 2013, p. 24). The paradox of his conception of the work of art is that it achieves permanence by yielding to "perpetual adaptation" (Arthos, 2013, p. 167). ${ }^{27}$

There is an identity to the work for Gadamer, but it is of a hermeneutic character. He even gives a strong example of how this identity can be experienced as present in improvisations: being a unique one-time performance does not take anything away from its identity. If we are able to pass judgement on a performance, then this also implies that we are able to grasp the unity of the work, taking it as an intended whole (1974/1986, p. 25; 1974/1993d, p. 116).

\section{Eco's "Open Work"}

Eco (1962/1989) links the "crisis of the work" to the advent of what he calls the "open work." This does not imply that the previously "complete and closed form" of "a balanced organic whole" would not have been open to interpretation and reception. The interpretative openness of the work has always been there. Eco's “open work" refers rather to how the formal determinations of the work of art have become open-ended. ${ }^{28}$ He notes that works

\footnotetext{
25 "worin objektive Gegebenheit und über-empirischer Bedeutungsgehalt vermittlungslos zusammengedacht sind [...] Im Werk realisiert sich Wahrheit für sinnliche Anschauung” (Bubner, 1973, p. 49).

${ }^{26}$ In place of the category of the work, Bubner suggests that of Schein: "Schein bezeichnet ontologisch, was das ist" (1973, p. 68).

${ }^{27}$ Also, in this respect Bubner's ontology of Schein approaches Gadamer's ontology (see Bubner, 1973, p. 70).

${ }^{28}$ Rebentisch (2015, p. 167) makes a distinction between bedeutungsoffene Kunstwerk and offenen Werkformen.
} 
like those of Stockhausen's Klavierstück XI and Berio's Sequence for Solo Flute “are 'open' in a far more tangible sense. In primitive terms we can say that they are quite literally 'unfinished" (Eco, 1962/1989, p. 4). In other words, the previously open meaning of the work is reinforced or emphasized through the work itself being "open" to modification.

Now, if Bubner is taking his cue from this way that modernism challenges the completeness of the work, then it seems that he is arguing from an ontic or historical change in the determination of the work towards an ontological feature already recognized in theory. Eco remarks much the same: the theoretical insight into the openness of interpretation has nowadays been appropriated by the artist "into a positive aspect of his production, recasting the work so as to expose it to the maximum possible 'opening"' (Eco, 1962/1989, p. 5). In other words, the theoretical insights of aesthetics have simply been confirmed on "the practical level of poetics" (Eco, 1962/1989, p. 22).

Yet, this does not mean that we can no longer speak of a work of art. Eco argues that even though works as "open" are in movement, this does not mean that they are no longer identifiable as works - “they will always be seen as 'works' and not just as a conglomeration of random components ready to emerge from the chaos" (1962/1989, p. 20). In this sense, Eco uses the dictionary as an example: "the dictionary is clearly open to the reconstitution of its raw material in any way [...] But this does not make it a "work"' (1962/1989, p. 20). Even though the "open work" is "susceptible to a whole range of integrations," it still has a "structural vitality," which is the "positive property of the work." And even though the work welcomes "all kinds of different conclusions," they will "never be gratuitously different” (Eco, 1962/1989, pp. 19-20). These conclusions largely support those of Gadamer.

\section{The Hermeneutically Structured Artwork}

Given the tension-filled history between philosophy and art, there seems to be only one way that Gadamer's thesis for the priority of the hermeneutic perspective can be judged as not representing a subsumption of art into philosophy. In other words, there is only one way that he can live up to his promise to do "justice to the experience of art," and that is if the work of art is considered hermeneutically structured.

This is the conclusion drawn by Welsch: Artworks are in themselves already hermeneutically constructed (1996, p. 225). ${ }^{29}$ For him (1996, p. 227), the commensurability thesis is as untenable as the incommensurability thesis: both positions exaggerate the state of affairs (Sachbehauptung), ultimately failing to see how the work of art is hermeneutically structured. This is what we need to consider if we are to overcome a misleading opposition between philosophy and art.

29 "Die Werke sind in sich selbst schon hermeneutisch verfaßt" (Welsch, 1996, p. 225). 
Leaving the particulars of the "open work" aside, Welsch's position essentially boils down to a remark on what it means to be able to speak to someone, what it means to have a language in common. He notes that the artwork may very well address us in an idiosyncratic fashion, ${ }^{30}$ however, this can never be said to occur solely from out of itself. ${ }^{31}$ Every gesture within art necessarily relates itself to gestures outside of art. Welsch exemplifies this claim by considering how the color blue can have different meanings depending on, for instance, the range of colors in the painting, symbolic conventions, the availability of the color, and cultural fashion. So that even if we were to argue for the autonomy of the artwork-like Bubner does - this autonomy, according to Welsch, cannot arise in isolation but only through interaction (1996, pp. 223-224). Welsch's (1996, p. 225) conclusion is that even the most autonomous of artworks is internally as well as externally hermeneutically structured. ${ }^{32}$

Gadamer's description of the structure of play, which aims to show us "the mode of being of the work of art itself" (1960/1989, p. 101), ${ }^{33}$ gives us a clear example of how the artwork could be said to have an externally constituted hermeneutical structure. However, the crucial question is whether we can find a characterization within Gadamer's hermeneutics that testifies to the artwork also having an internally constituted hermeneutical structure. One viable direction to take in this regard, is to consider Gadamer's account of the referential structure of the picture. ${ }^{34}$ However, what I shall propose is to consider his notion of aesthetic nondifferentiation as supplying us with the sought-after characterization. Yet, before venturing in this direction, let us consider a development of this notion of the hermeneutically structured artwork that takes into account the historical tensions between art and philosophy.

This is a line of argument developed by Herwitz (2012). He notes that the semblance of the self-sufficient autonomy of art is a product of how fine art was defined in opposition to other objects. Herwitz elaborates the point as follows:

The whole metaphor of art as a mode of spirit whose task was to acknowledge the times "by itself" is a product of the eighteenth century. The claim that art speaks, or has spoken, independently of a use, an enmeshment in life, a speech act, a form of rhetoric, is itself a product of the eighteenth-century distinction between fine and useful art. (2012, p. 223)

Herwitz points out that art has only ever been able to address us in relation to the world wherein it finds itself. According to the above depiction, art is enjoyed precisely as a counterweight to our otherwise instrumentally oriented activities. Thus, the aesthetic experience plays off of, is dependent upon, how we otherwise orient ourselves in everyday life. It is in this way that we need to envision art as being able to "speak" to us.

\footnotetext{
30 “spricht zwar auf eigene Weise" (Welsch, 1996, pp. 223-224).

31 “aber sie spricht nie allein aus sich" (Welsch, 1996, p. 223).

32 "Noch das geschlossenste Kunstwerk ist intern wie extern [emphasis added] hermeneutisch strukturiert" (Welsch, 1996, p. 225).

${ }^{33}$ See Gadamer (1960/1990, p. 107).

${ }^{34}$ See Gadamer (1960/1989, p. 154; 1960/1990, p. 157).
} 
Moreover, Herwitz argues that the recent turn towards philosophy in art—on Danto's description - maintains this general characteristic. If art previously appeared and addressed us in its contrast to useful objects, then after Duchamp blurred this distinction with his ready-mades, art turned to "philosophy" upholding the same relational structure. Herwitz argues in the following manner:

Then art's recent turn to philosophy, its current enmeshment with that particular norm (in so far as the norm is in fact in play), is simply the latest way for art to be itself, to have an identity, and to speak at all. (2012, p. 223)

Fine art contra useful things, art contra philosophy - these are for Herwitz only particular manifestations of art's ability to be meaningfully present.

\section{Art, Aesthetic Consciousness and Aesthetic Non-Differentiation}

This last remark lets us return one final time to our guiding thesis-“"Aesthetics has to be absorbed into hermeneutics" - not only as a question of the relationship between sound and sense, but rather as a question of the relationship between everyday (instrumental) understanding and art. ${ }^{35}$ If the aesthetic experience is not to be reduced to "a solitary monologue on private pleasure" (Davey, 2013, p. 33), then based on the foregoing arguments the artwork needs to be conceived of as relating itself to our understanding of the world.

One of the fundamental questions we have tried to actualize is what does it mean to consider art as art - especially within Gadamer's philosophical hermeneutics? Given his assurance that he aims to do justice to the experience of art, it is easy to be puzzled by strong formulations figuring as part of his critique of aesthetics consciousness - and, for instance, interpretations claiming that "We must destroy the aesthetic consciousness if we want to have access to the truth of art" (Grondin, 1999/2003, p. 22). How can we have access to the truth of art when we are no longer considering art as art? Given that aesthetic consciousness is responsible for giving us access to the artwork in the first place, such remarks are unsettling.

There are indeed places where Gadamer quite adamantly distances himself from the selfunderstanding of aesthetic consciousness (see 1960/1989, p. 100;1960/1990, p. 105) - a sense which is reinforced by him offering us complementary notions for hermeneutic consciousness. ${ }^{36}$ However, even though the task performed by aesthetic consciousness is judged an abstraction, its outcome, the pure artwork, is still deemed a positive achievement by Gadamer (1960/1989, p. 85; 1960/1990, p. 91). Taking course from our guiding thesis,

\footnotetext{
${ }^{35}$ In "Text and Interpretation" (1983/2007), Gadamer addresses this issue in an inquiry into the difference between everyday discourse and poetic speech.

${ }^{36}$ The tension between aesthetic consciousness and hermeneutic consciousness is further developed through the following contrasting pairs: against simultaneity (Simultaneität) we find contemporaneity (Gleichzeitigkeit), against lived experience (Erlebnis) we find experience (Erfahrung), against aesthetic differentiation we find aesthetic non-differentiation, against a distinction between form and content we find total mediation.
} 
we argue that we cannot simply take Gadamer's critique of aesthetics as a critical dismissal. We find support for such a reading in the following statement by Gadamer:

If, however, this aesthetic abstraction was subsequently understood as a content and was changed into the demand that art be understood "purely aesthetically," we can now see how this demand for abstraction ran into indissoluble contradiction with the true experience of art [zu der wirklichen Erfahrung der Kunst]. (1960/1989, p. 97; emphasis added) ${ }^{37}$

In other words, aesthetic consciousness is not dismissed out of hand, only its radical implementation. The challenge Gadamer's thesis presents us with is envisioning the artwork as lying in-between: as "autonomously" art, yet not severed from the world. In other words, our suggestion is that art becomes present as art when actualizing a productive tension with our world, with how we in an everyday manner relate to things.

On this view, Gadamer's critique of an aesthetic consciousness taken to the extreme implies that when aesthetic consciousness abstracts art from this relation, it necessarily even abstracts away the artwork itself. In this manner, we could say that Gadamer is arguing against the "aesthetization" of art, which risks considering art the product of an aesthetic attitude. For him, however, our approach to art is not explicitly thematized in the experience. ${ }^{38} \mathrm{He}$ therefore coins the notion of aesthetic non-differentiation.

In order to further open up this notion, we will begin by introducing a potentially misleading definition: "To appreciate an art object in its original non-aesthetic context is what Gadamer calls aesthetic non-differentiation" (Lawn \& Keane, 2011, p. 9). According to this definition, it sounds as if aesthetic non-differentiation implies appreciating art by reconstructing the original circumstances of its presentation: for instance, playing music with historically accurate instruments or repositioning artworks from the museum to the church from which they were once taken. However, Gadamer adamantly distances himself from such "historical bridging." 39

He calls reconstructing the "original non-aesthetic context" a "futile undertaking" - in that what is brought to life is not the artwork lost. This is not to say that historical knowledge could not aid understanding; yet, as Gadamer (1960/1989, p. 167) himself asks in this context, do we really obtain "the meaning of the work of art that we are looking for" in this manner? ${ }^{40}$

\footnotetext{
${ }^{37}$ See Gadamer (1960/1990, p. 103).

${ }^{38}$ This is partly what he means by "total mediation," that is, "the medium as such is superseded" (Gadamer, 1960/1989, p. 120). See Gadamer (1960/1990, p. 125).

${ }^{39}$ Gadamer forcefully begins the essay "Aesthetics and Hermeneutics" (1964/1977) by stating that if hermeneutics becomes the "bridging [Überbrückung] of personal or historical distance between minds, then the experience [Erfahrung] of art would seem to fall entirely outside its province" (p. 95). This act of bridging belongs to historical consciousness. See Gadamer (1964/1993b, p. 1).

${ }^{40}$ See Gadamer (1960/1990, p. 172).
} 
For clarity's sake we can elucidate the notion of aesthetic non-differentiation concretely in terms of the museum, which figures as the social correlate of aesthetic consciousness. In this manner, we can say that Gadamer is not dismissing the existence of museums or discouraging us from visiting them, in that there we would only be shown works inauthentically present. On the contrary, the reason art is the model for hermeneutics is that the museum perfectly shows us the manner in which the work of art is present for hermeneutic consciousness. Gadamer utters the same idea generally as follows: "even if every 'work' belongs originally to a context of life that has passed away, nevertheless the doctrine of aesthetics non-differentiation implies that this relation to the past is, as it were, retained in the work itself" $\left(1960 / 1989\right.$, p. 578). ${ }^{41}$

We can take Gadamer's (1981/1993e, p. 261) words on how Rilke's letters become art as illuminating the point. When a letter is considered literature, we see that it no longer functions as a letter. The specific context also becomes of secondary importance. Appreciating the letter as literature, we need not know who the intended recipient was or Rilke's rapport to the person in question. Nevertheless, in accord with what Gadamer states above, we also realize that even though the letter as literary art is no longer (merely) a letter, it still bears the mark of being a letter- that is so to say, "retained in the work itself."

In Truth and Method, the clearest example Gadamer gives us in this context is that of the work of architecture. In considering what makes a building a work of art, Gadamer $(1960 / 1989$, p. $156 ; 1960 / 1990$, p. 161) notes that the contexts of purpose and life (Zweckzusammenhang und Lebenszusammenhang) are not only retained in the artwork, but present: the artwork retains a trace (Spur) of its original purpose (Bestimmung), which cannot be effaced (auslöschen). Were this to happen, then the artwork - in this case the building itself-would become "incomprehensible [unverständlich]" (Gadamer, 1960/1989, pp. 155-156). ${ }^{42}$

\section{Concluding Remarks}

The preceding inquiry has focused on Gadamer's claim that "Aesthetics has to be absorbed into hermeneutics." We have contextualized the claim in an effort to bring out the potentially provocative nature associated with it. In addition, we have also considered how Gadamer's argument reaches from a focus on art to the purely aesthetic, in which case his thesis becomes a commonsensical argument against sense data. Towards the end of the paper, we have argued that in order for Gadamer's claim not to represent a subsumption of art into philosophy, the artwork itself needs to be conceived of as hermeneutically structured. With Gadamer's notion of aesthetic non-differentiation, we have presented an account of how this can be considered so.

\footnotetext{
${ }^{41}$ See Gadamer (1972/1993a, p. 477).

${ }^{42}$ See Gadamer (1960/1990, pp. 160-161).
} 


\section{References}

Adorno, T. (1986). Aesthetic Theory. (C. Lenhardt, Trans.). London, UK: Routledge \& Kegan Paul. (Original work published 1970)

Arthos, J. (2013). Gadamer's poetics: A critique of modern aesthetics. New York, NY: Bloomsbury Academic.

Bubner, R. (1973). Über einige Bedingungen gegenwärtiger Ästhetik. Neue Hefte für Philosophie, $5,38-73$.

Danto, A. (2014). After the end of art: Contemporary art and the pale of history. Princeton, NJ: Princeton University Press.

Davey, N. (2013). Unfinished worlds: Hermeneutics, aesthetics and Gadamer. Edinburgh, UK: Edinburgh University Press.

Dufrenne, M. (1973). The phenomenology of aesthetic experience. (E. S. Casey, A. A. Anderson, W. Domingo, \& L. Jacobson, Trans.). Evanston, IL: Northwestern University Press. (Original work published 1953)

Eco, U. (1989). The open work. (A. Cancogni, Trans.). Cambridge, MA: Harvard University Press. (Original work published 1962)

Figal, G. (2015). Aesthetics as phenomenology: The appearance of things. (J. Veith, Trans.). Bloomington, IN: Indiana University Press. (Original work published 2010)

Figal, G. (2016). Aesthetics and perception. In N. Keane \& C. Lawn (Eds.), The Blackwell companion to hermeneutics (pp. 220-227). West Sussex, UK: Wiley Blackwell.

Gadamer, H.-G. (1977). Aesthetics and Hermeneutics. In D. E. Linge (Ed. \& Trans.), Philosophical hermeneutics (pp. 95-104). Berkeley, CA: University of California Press. (Original work published 1964)

Gadamer, H.-G. (1984). The Hermeneutics of suspicion. In G. Shapiro \& A. Sica (Eds.), Hermeneutics: Questions and prospects (pp. 54-65). Amherst, MA: Massachusetts University Press.

Gadamer, H.-G. (1986). The relevance of the beautiful: Art as play, symbol, and festival. In R. Bernasconi (Ed.) \& N. Walker (Trans.), The relevance of the beautiful and other essays (pp. 353). Cambridge, UK: Cambridge University Press. (Original work published 1974)

Gadamer, H.-G. (1989). Truth and method (2 $2^{\text {nd }}$ ed., J. Weinsheimer \& D. G. Marshall Trans.). New York, NY: Continuum. (Original work published 1960)

Gadamer, H.-G. (1990). Wahrheit und Methode: Grundzüge einer philosophischen Hermeneutik (Gesammelte Werke 1) (6 $6^{\text {th }}$ ed.). Tübingen, Germany: J.C.B. Mohr (Paul Siebeck). (Original work published 1960)

Gadamer, H.-G. (1993a). Nachwort zur 3: Auflage. In H.-G. Gadamer, Wahrheit und Methode: Ergänzungen, Register (Gesammelte Werke 2) (2 ${ }^{\text {nd }}$ ed.; pp. 449-478). Tübingen, Germany: J.C.B. Mohr (Paul Siebeck). (Original work published 1972)

Gadamer, H.-G. (1993b). Ästhetik und Hermeneutik. In H.-G. Gadamer, Kunst als Aussage (Gesammelte Werke 8) (pp. 1-8). Tübingen, Germany: J.C.B. Mohr (Paul Siebeck). (Original work published 1964) 
Gadamer, H.-G. (1993c). Dichtung und Mimesis. In H.-G. Gadamer, Kunst als Aussage (Gesammelte Werke 8) (pp. 80-85). Tübingen, Germany: J.C.B. Mohr (Paul Siebeck). (Original work published 1972)

Gadamer, H.-G. (1993d). Die Aktualität des Schönen. Kunst als Spiel, Symbol und Fest. In H.-G. Gadamer, Kunst als Aussage (Gesammelte Werke 8) (pp. 94-142). Tübingen, Germany: J.C.B. Mohr (Paul Siebeck). (Original work published 1974)

Gadamer, H.-G. (1993e). Stimme und Sprache. In H.-G. Gadamer, Kunst als Aussage (Gesammelte Werke 8) (pp. 258-270). Tübingen, Germany: J.C.B. Mohr (Paul Siebeck). (Original work published 1981)

Gadamer, H.-G. (2007). Text and interpretation. In R. E. Palmer (Ed. \& Trans.), The Gadamer reader: A bouquet of the later writings (pp. 157-191). Evanston, IL: Northwestern University Press. (Original work published 1983)

Grondin, J. (1998). Gadamer and the truth of art. In M. Kelly (Ed.), Encyclopedia of aesthetics (Vol. 2, pp. 267-271). New York, NY: Oxford University Press.

Grondin, J. (2003). The philosophy of Gadamer (K. Plant, Trans.). Chesham, UK: Acumen. (Original work published 1999)

Herwitz, D. (2012). The beginning of the end: Danto on postmodernism. In M. Rollins (Ed.), Danto and his critics (pp. 215-231). Malden, MA: Wiley-Blackwell.

Lawn, C., \& Keane, N. (2011). The Gadamer dictionary. New York, NY: Continuum.

Rebentisch, J. (2015). Theorien der Gegenwartskunst zur Einführung (3 ${ }^{\text {rd }}$ ed.). Hamburg, Germany: Junius.

Vattimo, G. (1997). Beyond interpretation: The meaning of hermeneutics for philosophy (D. Webb, Trans.). Cambridge, UK: Polity Press. (Original work published 1992)

Welsch, W. (1996). Grenzgänge der Ästhetik. Stuttgart, Germany: Reclam. 